\title{
Social model and educational ethos: A possible conflict in edu- cation for citizenship
}

\author{
Alfredo Rodríguez-Sedano ${ }^{1}$, Aurora Bernal ${ }^{2}$, Miguel Rumayor ${ }^{3}$
}

This article endeavours to approach education for citizenship from a social perspective. This requires, firstly, reference to the civilization in question, to the kind of society dealt with and its foundations. Next, attention is paid to the educator. Could one count with a teaching ethos that could offer a response to the teachings needs of an education for citizenship? With regard to the educand, the attitudes that should be encouraged for such an education to be effective are emphasized. Both proposals establish guidelines for the development of a curriculum in education for citizenship. [Article copies available for a fee from The Transformative Studies Institute. E-mail address: journal@transformativestudies.org Website:

http://www.transformativestudies.org (02009 by The Transformative Studies Institute. All rights reserved.]

KEYWORDS: Social Model, Ethos, Education for Citizenship, Virtues, Profession, Globalization.

\section{INTRODUCTION}

In order to approach education for citizenship, civic, moral and political education, it is firstly necessary to make reference to the civilization that

\footnotetext{
${ }^{1}$ Alfredo Rodríguez-Sedano, Ph.D., is Professor of Sociology, Education Department, University of Navarre (Spain). Address correspondence to: Dr. Alfredo RodríguezSedano, Education Department of the University of Navarre, 31080 Navarre, Spain; tel: +34948 425600; e-mail: arsedano@unav.es.

2 Aurora Bernal, Ph.D., is Professor of Anthropology of Education and Ethics, Education Department, University of Navarre (Spain). Address correspondence to: Dr. Aurora Bernal, Education Department of the University of Navarre, 31080 Navarre, Spain; tel: +34948 425600; e-mail: abernal@unav.es.

${ }^{3}$ Miguel Rumayor, Ph.D., is Professor of Philosophy of Education and Ethics, Education Department, University Panamericana Guadalajara (México). Address correspondence to: Dr. Miguel A. Rumayor, Education Department of the Univesidad Panamericana, Calz. Nueva No. 49, Ciudad Granja, 45010 Zapopan, Jalisco, México; e-mail: mrumayor@up.mx.
} 